\title{
Changing Cities and Changing Lives: Development Induced Displacement in Kochi, Kerala
}

\author{
Ann George ${ }^{1, a}$ and Irudaya Rajan. $S^{2, b}$ \\ ${ }^{1}$ Union Christian College, Aluva, Kerla, India \\ ${ }^{2}$ Centre for Development Studies, Trivandrum, India \\ ann.t.george@gmail.com, ${ }^{\mathrm{b}}$ rajan @ cds.ac.in,
}

\begin{abstract}
In the recent two decades, post liberalisation, the landscapes of Kochi city, (a city in Ernakulam, the central district of the state of Kerala, India) and its suburbs are witnessing fast changes with the launch of several mega projects. As the city and its suburbs are reinventing, this paper examines the lives of those people most affected by these changing geographies, namely those displaced by the projects. We specifically examine the poverty, inequality and violence nexus associated with displacement which was noted in other parts of India. It is interesting to examine this question in context of Kerala, as the state has received much acclaim for its pro-poor and propublic approach and people have received some acclaim for their public action. It would be relevant to see whether the experiences of displaced would be similar or different in such a state. Both quantitative and qualitative methods of enquiries were used.

Our quantitative survey revealed that poverty, inequality (within the locality) and violence and physical safety did not emerge as significant concerns. What emerged as poignant concern was the different forms of state violence- be it in terms of brute force or in terms of indifference, negligence, inefficiencies leading to great deal of unnecessary suffering for the displaced. Our qualitative interviews also revealed people's remarkable agency as they struggled and agitated to get a fair compensation. In the urban or urbanising context of city and its suburbs, where fundamental conflicts over land acquisition is found as coming down, people would be willing to bear the hardships of displacement and resettlement if the rehabilitation package allows them to settle even a little better. The state, which claims to be pro-people would well have avoided the unnecessary suffering of the displaced.
\end{abstract}

Keywords: Displacement, Poverty, Inequality, Violence

\section{Introduction}

In the recent two decades, post liberalisation, the landscapes of Kochi city, (a city in Ernakulam, the central district of the state of Kerala, India) and its suburbs are witnessing fast changes with the launch of several mega projects. As the city and its suburbs are reinventing, this paper examines the lives of those people most affected by these changing geographies, namely those displaced by the projects. Literature on development induced displaced in India has shown several evidences of impoverishing 
International journal on urban environments

and inequality exacerbating impacts of displacement. Literature also discusses several forms of violence characterising the displacement experiences of many a displaced. By violence, we are referring to the broad definition of violence used by WHO (2002), which incorporates not just activities causing physical harm but also acts of omission and commission involving those activities causing neglect and psychological harm. In such context, our study examines the poverty, inequality and violence nexus of the displacement in Kerala, a state lying in the south west tip of India. Kerala has received significant national and international attention for its achievements in human development ${ }^{\mathrm{a}}$. The achievement of high human development is largely attributed to its history of public action - of caste based social reform movements in the pre-independence period (along with progressive measures of the state and Christian missionaries) and of class based political movements of people for their various rights and welfare in the post independence period. The context of Kerala is interesting and relevant to examine whether the displacement experience would be similar or different in a state with historical precedence of struggles of the people and a pro-poor approach by the state, when compared to experiences elsewhere in the country. Displacement experiences of six most recent development projects, the land acquisition of which happened after 2000, are examined in this paper. The paper, speaks both from quantitative analysis and intensive interviews.

The paper is organised in the following manner. Section 2 gives a brief review of literature on the nexus of poverty, inequality and violence in relation to displacement. Section 3 discusses the area of the study, namely the suburban region of Kochi city, methodology used in the study and the limitations of the study. Section 4 speaks from quantitative data and presents the key findings related to the questions on poverty, inequality and violence. Section 5 speaks from qualitative data and describes the various forms of state violence and people's agency in fighting impoverishment, inequality and state violence. It also discusses the heterogeneity in experiences of the displaced. Section 6 concludes.

\section{Displacement -Poverty- Inequality- Violence nexus in India}

The literature on development induced displacement in India can be categorised into two. First is the displacement of rural and tribal population from their land, livelihood, socio-cultural milieu and way of life leading to very stark consequences. Another is a more recent phenomenon of displacement of the poor in urban contexts, while being less stark in terms of the apparent resemblance of socio-economic milieu is also poverty inducing or perpetuating.

Post independence, large scale displacement took place for the construction of dams and industrial expansion since 1950s. There are many moving accounts of the impacts of displacement of rural and tribal population whose lives are so intricately related to land and nature around them. These accounts talk about drastic relocationfrom self sufficiency, earning an extra income, having healthy and natural food, living in relation to animals, plants and the world of nature to an entirely different terrain, their

${ }^{\mathrm{a}}$ The India Human Development Report, 2011 prepared by Institute of Applied Manpower Research placed Kerala on top in the human development index. 
International journal on urban environments

livelihood and mobility possibilities changed/limited or curtailed and having to bear many extra costs (for one such recent study, see Cook, Bhatta and Dinker, 2013).

Cash compensation, rather than restitution of livelihoods has been a common practice and when land is given, the quality of land is inferior. Many studies point out how just receiving cash compensation is often tantamount to assured destitution as cash is used up for several purposes like meeting old debts or in conspicuous consumption or increased alcoholism. Even if one does not splurge away cash, the very mechanisms of compensation are poverty inducing. Rather than paying replacement value, the practice is to pay compensation for lost fixed assets like agricultural land at the prevailing market rate. However, it is an open secret that most land transactions in India are grossly undervalued to evade registration fees. It is quite often the case that by the time they rebuild their assets, the costs far exceed the compensation amount leading to heavy indebtedness. Besides, those without legal title to land, tenants, sharecroppers, wage-labourers, artisans and encroachers are usually not considered eligible for compensation. Community assets like grazing grounds and forests, which again may be critical for the livelihood of the poorest, are not compensated for under the land acquisition act of India (EPW Editorial, 2014; Sarma, 2011; Sampat, 2014).

The urban counterpart of these experiences is more about modernising the cities post globalisation cleansing it of its slums catering to the rising aspirations of a vocal middle class, termed by one scholar as bourgeoisie environmentalism ${ }^{\mathrm{b}}$. Across the three cities of Delhi, Ahmedabad and Chennai, the impoverishing effects of displacement of the poor from slums is shown by different studies (Baviskar, 2011; Bhan and Shivanand, 2013; Mathur, 2012; Coelho et al., 2012 ).

To begin with, a large share of the poor are not resettled. For instance, in Delhi, the average resettlement for the studied evicted sites is only 52 percent. The absence of proper housing documents coupled with arbitrary eligibility requirements that require families to be residents of slums before such and such dates are reasons, due to which many a poor do not even benefit from resettlement. Even if the displaced are resettled, it is often in the fringes of cities. In both Delhi and Ahmedabad scholars note how some of these sites are no better than waste lands and creates costly distances between place of residence and established work and work relations (Baviskar, 2011; Mathur, 2012).

Continuity or longevity of employment is an important channel for the poor for upward mobility limited as it may be. This is ruptured when people are displaced from their existing settlements. Coelho et. al(2012) notes in their study on displacement in Tamil Nadu, that during the early waves of resettlement, although the resettlement colony was situated near an IT corridor, jobs were not easy to come by due to lack of networks to give recommendation and contacts and due to the stigma attached to these colonies. Some could not find jobs as their skills were not in demand in the new location.

Despite these adverse consequences, scholars note, for many a poor, displacement and resettlement does give hope or sense of opportunity - for instance of getting legal entitlements to a house- as one scholar terms, displacement as twin faced for the poor (Bhan and Shivanand, 2012). Relocation might mean better job

${ }^{\mathrm{b}} \mathrm{http}: / /$ www.india-seminar.com/2002/516/516\%20amita\%20baviskar.htm as accessed on 03-07-2015 
International journal on urban environments

opportunities for some. Compensation cash could benefit those who are in some dire need for money. Therefore it is imperative to examine the positives, if any in analysing impacts of displacement.

As for relation of displacement to inequality, going by indirect evidence one can say that most often, poor people are the victims of development induced displacement. Construction of big dams is reportedly responsible for the largest share of displacement in the rural- tribal context. It is the poor who paradoxically inhabit the resource rich geographies, who are then displaced. Slum cleansing accounts for a major share of urban displacement. As studies have noted, the pauperisation of the poor in such times is tantamount to increasing inequality. The other way relation of inequality leading to displacement is also obvious; as inequality increases and as material prosperity increases of a section of people, they demand better quality of life, leading then to aspirations of world class cities, exploitation of more natural resources and so forth. Examining relation of development induced displacement to violence, what one sees commonly in all studies is violence by the state. The poor are subjected to three categories of violence - of structural violence, the violence of omission (where the state fails to give adequate information at any stage of displacement) and acts of commission (of brutal force to evict and to suppress any dissent). The state fails to consult and inform the people in advance. This is true of the earlier development projects like Narmada Dam Project (but improving now with a much more modified law on land acquisition). In this case the concerned officials hardly visited the resettlers, rather it is through survey teams bits and pieces of information are gathered by the people. Rehabilitation has been adhoc, piecemeal and minimalistic. While this is the case with regard to the discharge of duties of the state, when it comes to people refusing to leave, state does not hesitate from using force with vigour and zeal. Brutal violence of state is found in the earlier times like that of Narmada Dam and continue even in the more recent episodes of beautification of cities. Studies of displacement in Delhi and Ahmedabad notes how the state demolished the houses of the evictees with impunity. These forced evictions, as the study on displacement in Ahmedabad notes, were not sensitive to the harsh weather (harsh winter or scorching summer) when people had to move to interim camps with horrid living conditions. The Ahmedabad Municipal Corporation made no effort to provide any services while these people languished around their broken homes, but deployed hundreds of police personnel so that there would be "no trouble". Infants died due to severe cold. Pregnant women died on the way to the hospital or suffered miscarriages" (Mathur, 2012). Not even providing basic services in interim camps leading to death, yet deploying police personnel to see that there is no trouble is quite typical of state's dealing of poor.

It is not just the state alone, but very institutions, especially the judiciary supposed to be supportive of poor adopt anti poor stand at times based on naïve understanding of lives of the poor or the systems catering to them. Scholars examining Delhi's displacements note that many of the evictions are the results of orders of Delhi high court or supreme court issued in public interest litigations. Scholars note how the courts have characterised the poor as encroachers, ignoring the structural imperatives behind squatting on public land (Baviskar, 2011). 
International journal on urban environments

On the other hand, there are instances of court giving favourable verdicts, only to be by passed by state government to meet their objective of slum cleansing. In case of Sabarmati river front, for instance, even after the chief justice issued orders to the municipal authority to cease and desist any evictions and demolitions without completing and allotting rehabilitation housing, the Ahmedabad Municipal Corporation continued demolitions of hundreds of homes for the next couple of days with impunity.

The tragedy of this violence magnifies from the fact, observed in a study, that much of the land appropriated by eviction lie vacant even after passing of many years. Examining the land use of the appropriated land, the study notes how in the vacant land category, there are at least 51 evicted sites - accounting for the displacement of a minimum of 21,551 families - that have remained fully or partially vacant between four and 21 years (Bhan and Shivanand, 2012).

Another violence talked in relation to displacement is domestic violence or crime against women arising from increased alcoholism. Loss of self- esteem or fall in status of the men, especially in their own eyes, often manifests itself in increased violence against the women and children. The sale of liquor in resettlement colonies constitutes a major threat both of violence and pauperisation for women. Also noted is how women tend to feel more insecure in alien surrounding, thereby increasing their dependence on men (Asthana, 2012).

\section{Area of Study, Methodology and Limitations}

Kochi was selected as the city for study as the city and its suburbs witnessed the commissioning of several mega development and infrastructure projects since the beginning of the millennium leading to displacement of several families. Kochi is a coastal city partly surrounded by the Vembanad lake, which opens out to the Arabian sea and partly by the sea itself. Kochi city, strictly speaking would fall under a limited region coming under the administrative category of Cochin Municipal Corporation. However, given the urban character of its suburbs, be in terms of the dominant economic activities, infrastructure and amenities, the new industry/infrastructure projects coming up, Census 2011 now considers a broader region of Kochi to include its suburbs. This is called the Kochi metropolitan region or Kochi urban agglomeration coming under the Million plus UA/city ${ }^{\mathrm{c}}$. The exact areas of this study, where displacement took place would fall under the larger Kochi metropolitan region.

Kochi developed as the commercial and industrial centre of Kerala because of having an all weather harbour, access to cheap hydro electric power and good water. Post liberalisation, Kochi is gaining further importance as an industrial centre because of its strategic location. A good deal of central government investments in infrastructure and industry is now flowing to Kerala and Kochi particularly after 2000. The international container trans-shipment terminal (ICTT), Liquidified Natural Gas plant (LNG), gas pipeline across state, smart city, expansion of Kochi refinery are among the major

\footnotetext{
${ }^{\mathrm{c}}$ An urban agglomeration is a continuous urban spread constitution a town and its adjacent urban outgrowth (OGs- referring to villages with urban like infrastructure and facilities) or two or more contiguous towns and their urban outgrowths
} 
International journal on urban environments

projects. The recent projects have also brought dramatic visual changes to the city in terms of the once isolated islands now being connected to the main land through bridges (the construction of which involved land reclamation from lake), marshy and largely abandoned stretches of land strengthened to build heavy investment industrial plants, new highways and rail lines (including the longest rail bridge in India) criss-crossing isolated village, islands, backwaters and rivers and the mushrooming of several high rises.

\section{Methodology}

The study consisted of quantitative survey and qualitative field work. A survey was conducted on both internally displaced persons (IDPs- 377 households) and non-IDPs (448 households). Inclusion of non-IDPs in the survey is to assess if the dimensions revealed of the IDPs are considerably different from the general population. The criterion was to consider those projects, where the resettlement does not date back more than 10 years to the date of our survey. We have considered a total of 7 major projects and miscellaneous minor projects which led to the displacement of people from their homes. The projects considered are the construction of Goshree bridges connecting three cut off islands to the main land of Ernakulam; Smart city, the commissioning of a special economic zone for IT industries; International Container Transshipment Terminal (ICTT) built with the aims of enabling Kochi to serve as a premier gateway to south India; liquid and natural gas plant commissioned in Puthuvyppe; Waste plant in Brahmapuram meant to address the massive problem of waste management confronting the city administration and Perandur canal widening project which displaced people who had squatted on the banks of the canal. We surveyed all the displaced whom we could track and were willing to be interviewed. The survey was conducted during November 2013- January 2014. A structured and largely pre-defined questionnaire was used. With regard to non-displaced, we adopted the criteria of taking them from the source of displacement. Random sampling was done to avoid bias in the selection of non-IDPs. Our qualitative analysis consisted of 22 intensive interviews. In the interviews, we tried to understand what the displaced themselves narrated as their core grievances.

\section{Limitations}

The survey considered only those displaced families, who could be tracked and who were willing to talk. In case of ICTT project which displaced the largest number of people, we could not track the whereabouts of more than 100 families. Our findings are limited to that extent.

\section{Poverty, Inequality and Violence in Displacement in Kochi}

Literature referred to above showed the different processes through which impoverishment and violence takes place. In the following discussion we examine if impoverishment has taken place by examining several material aspects of their lives.

\section{Socio-economic background of the IDPs and non-IDPs}


International journal on urban environments

To begin with we examined the socio- economic background of the IDPs and non-IDPs.

Table 1: Socio- economic background of the IDPs and non-IDPs

\begin{tabular}{|l|c|c|}
\hline & $\begin{array}{c}\text { IDP } \\
\text { (in percentage) }\end{array}$ & $\begin{array}{c}\text { Non-IDP } \\
\text { (in percentage) }\end{array}$ \\
\hline $\begin{array}{l}\text { Households falling in the Above } \\
\text { Poverty Line list }\end{array}$ & 75.6 & 73.9 \\
\hline $\begin{array}{l}\text { Head of the household having less } \\
\text { than Class 10 education }\end{array}$ & 76.9 & 72.8 \\
\hline $\begin{array}{l}\text { Head of the household having } \\
\text { Class 4 jobs }\end{array}$ & 69.1 & 66.7 \\
\hline
\end{tabular}

It may be inferred that the displaced belonged to the lower middle class families, who although are not the official poor have low levels of education and Class 4 jobs or what may be called working class jobs like construction labourers, carpenters, street vendors, shop keepers etc. However, the fact that the non- displaced also seem to be having similar characteristics does suggest that within a region, there has been no targeting of the weaker sections alone for displacement(although there are allegations of projects itself being realigned to suit the interests of the elite).

\section{Details of resettlement}

Have the people resettled? How far they have resettled and how soon have they resettled are the questions examined in the next discussion. Table 2 gives the results.

Table 2: Details of resettlement

\begin{tabular}{|l|c|c|}
\hline & IDP & Non-IDP \\
\hline $\begin{array}{l}\text { Average years passed } \\
\text { since displacement }\end{array}$ & 7 years & - \\
\hline Ownership with deeds & $81.2 \%$ & - \\
\hline $\begin{array}{l}\text { Average years taken to } \\
\text { resettle }\end{array}$ & 2.4 & \\
\hline $\begin{array}{l}\text { Proportion of people } \\
\text { settling in 0-1 } \\
\text { kilometre distance }\end{array}$ & 72.4 & \\
\hline
\end{tabular}

Two positive outcomes emerge. One is that after the passing of an average of 7 years since their displacement, we found overwhelming majority as resettled. Second, as we can see in the table, most of the displaced could resettle within $1 \mathrm{~km}$ of their source of displacement. In comparison, a study of displacement in Delhi gives the distance of some resettlement sites to place of work as 20-30 kilometres; and in

\footnotetext{
d State governments categorise people officially into below poverty line and above poverty line families for the distribution of several welfare schemes and programs of both state and central government.
} 
International journal on urban environments

Sabarmati river front displacement of Ahmedabad the average distance between previous home and the current residence is around 9 kilometres. When compared to that, resettlement has been quite near for most of the displaced in our sample.

\section{Land ownership and housing}

The material conditions of the IDPs are compared to their conditions before displacement and with that of the non-IDPS. The results are presented in the table below.

Table 3: Land and housing

\begin{tabular}{|c|c|c|c|c|c|c|c|c|c|c|c|c|}
\hline & \multirow[t]{2}{*}{ 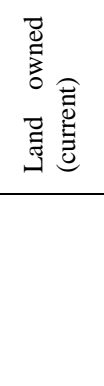 } & \multirow[t]{2}{*}{ 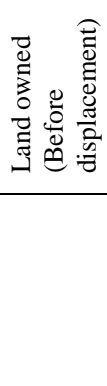 } & \multirow[t]{2}{*}{ 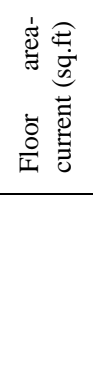 } & \multirow[t]{2}{*}{ 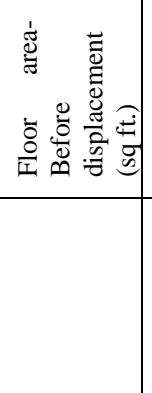 } & \multicolumn{2}{|c|}{ 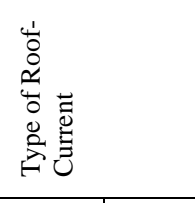 } & \multicolumn{2}{|c|}{ 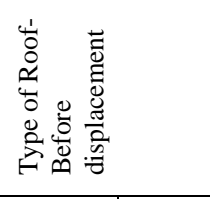 } & \multicolumn{2}{|c|}{ 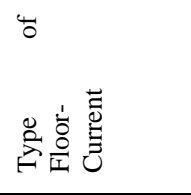 } & \multicolumn{2}{|c|}{ 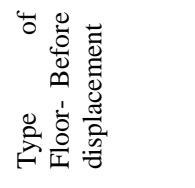 } \\
\hline & & & & & 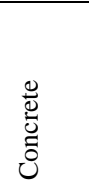 & 胥 & 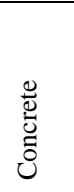 & 疍 & 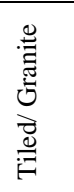 & 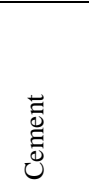 & 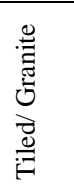 & $\begin{array}{l}\overrightarrow{\bar{E}} \\
\text { Uूँ } \\
\text { Un }\end{array}$ \\
\hline IDPs & 8.12 & 26.0 & 936.3 & 806.8 & 79.6 & 10.9 & 28.9 & 58.9 & 69.2 & 28.6 & 13.5 & 79.3 \\
\hline Non-IDPs & 15.34 & & 815 & & 67.9 & 30.8 & & & 54.4 & 44.6 & & \\
\hline
\end{tabular}

Figures are the percentages or the proportion of people reporting a particular type of roof, floor etc. Land owned is given in cents.

As one can see from the table, average land ownership has clearly fallen for the IDPs from earlier times, despite being some land given for rehabilitation. The state had given 3-7 cents of land to the displaced of different projects for their rehabilitation. The non-displaced has an average land ownership of 15.34 cents. The difference in average land ownership between the displaced and non-displaced is 7.2 cents of land, value of which has increased manifold due to the development projects.

Having a house of one's own is very important for an individual. In Kerala, housing is one domain where people invest with passion for both its use and symbolic value. As we can see from the table, a loss in area of land owned in a way, transformed to 'better' houses suiting 'latest trend and fashion'. Majority of the IDPs had tiled roof before displacement. The floor area has increased from before displacement times and it is more than that of the non-displaced. On resettling, most of the people have made concrete roof. Concrete roofs are considered more trendy and convenient (for cleaning) among the masses although there is a reversal of tiled roofs among the rich and elite. With regard to flooring, the 'progress' is more obvious. Most of the displaced had cement flooring before displacement. Currently, majority of displaced have tiled/ granite flooring. A comparison with non-IDPs show that while non-IDPs fared better than IDPs in land ownership, a considerably higher proportion of IDPs are enjoying better features of housing than the non-IDPs. 
International journal on urban environments

\section{Possession of consumer durables}

Possession of basic amenities and consumer durables are indicators of an individual's living standards. In the following discussion we are examining if living standards represented by possession of basic amenities and consumer durables have changed for IDPs after displacement and how does their current situation compare with the non-IDPs.

Table 4: Basic Amenities and Consumer Durables

\begin{tabular}{|l|r|c|c|}
\hline \multirow{2}{*}{ Basic Amenities } & \multicolumn{2}{|c|}{ IDP } & Non-IDP \\
\cline { 2 - 4 } & Current & Before Displacement & Current \\
\hline Having private toilet & $370(98.1)$ & $353(93.6)$ & $446(99.6)$ \\
\hline Tap Private & $287(76.1)$ & $203(53.8)$ & $335(74.8)$ \\
\hline Electricity & $373(98.9)$ & $341(90.5)$ & $445(99.3)$ \\
\hline LPG/ Electricity as fuel for cooking & $329(87.2)$ & $257(68.2)$ & $400(89.3)$ \\
\hline Owning a television & $360(96.5)$ & $306(81.2)$ & $435(97.1)$ \\
\hline $\begin{array}{l}\text { Having telephone (Landline or } \\
\text { mobile) }\end{array}$ & $367(97.3)$ & $289(76.7)$ & $438(97.8)$ \\
\hline Computer & $89(23.6)$ & $33(8.8)$ & $114(25.4)$ \\
\hline Motor cycle / Three wheelers & $230(61.0)$ & $165(43.8)$ & $260(58.0)$ \\
\hline Car/ Van & $66(17.5)$ & $26(6.9)$ & $87(19.4)$ \\
\hline Having additional land/ house & $119(31.6)$ & $41(10.9)$ & $42(9.4)$ \\
\hline
\end{tabular}

Having a private toilet, electricity in the house and owning a television and phone is nearly universal for both the displaced and non-displaced. Around three-fourth of the displaced and the non-displaced used LPG or electricity for cooking and had a private tap. More than a majority own two wheelers/ three wheelers. It is only in having a car/ van, a computer and having additional land that majority in both groups are found lacking.

What is striking is that for the displaced, there is a marked difference with regard to each and every amenity/ consumer durable considered in the current period than before displacement, particularly in case of private tap connection, using LPG fuel/ electricity for fuel, or possessing a phone, motorcycle or three-wheeler, television, computer or an additional piece of land. A higher proportion of the displaced owned an additional plot of land, probably referring to the rehabilitation land given for their resettlement. 
International journal on urban environments

Comparison between IDPs and non-IDPs shows a slightly higher proportion of non-IDPs having private toilet, electricity, LPG or electricity based cooking facilities, possessing television, telephone, computer and car or van. A slightly higher proportion of IDPs have private tap connection and motorcycles or three wheelers. A considerable difference exists only in the case of additional land/house with a higher proportion of ownership for the IDPs possibly because of the rehabilitation land given.

\section{Average monthly income}

In this study we have collected three categories of income, namely the income from employment, income from other sources (including interest or dividend income, remittances, rent/ lease/ rent allowance, public assistance or income from secondary employment) and total income (which is an addition of the above two). Table presents the average income of these three categories for the IDPs and non-IDPs. Table gives the average of the summation of incomes of all members in a family.

Table 5: Average monthly income from Employment and Other Source of IDPs and Non IDPs

\begin{tabular}{|l|c|c|c|c|c|c|c|}
\hline \multirow{7}{*}{} & \multicolumn{2}{|c|}{$\begin{array}{l}\text { Income from } \\
\text { employment }\end{array}$} & \multicolumn{2}{|c|}{ Other Income } & \multicolumn{2}{|c|}{$\begin{array}{c}\text { Total } \\
\text { Income }\end{array}$} & \\
\cline { 2 - 9 } & $\mathrm{N}$ & Mean & N & Mean & N & Mean & \\
\hline IDP & 367 & 16785 & 73 & 8124 & 371 & 18203 & \\
\hline NON IDP & 429 & 18551 & 41 & 6697 & 439 & 18754 & \\
\hline Total & 796 & 17737 & 114 & 7611 & 810 & 18502 & \\
\hline
\end{tabular}

Income from employment is higher for the non-IDPs than the IDPs. With regard to other income, IDPs earn higher than the non-IDPs. What is important to note is however that there is not any substantial difference between the IDPs and non-IDPs in the total income earned. We may infer that the income earning capacity of the displaced is not significantly impacted by their displacement. This is further reinforced when most of the resettled (80.6 percent) reported that they did not find any change in their job availability or income earnings post displacement, possibly because people have managed to resettle in close distance itself.

\section{High levels of debt}

The narratives of the displaced ask us to go beyond the obvious indicators of progress to look at their accumulated debt. Wanting to counter the perception of rebuilding houses through compensation amount and wanting acknowledgement for their long struggles, people point out that the compensation amount despite the DLPC 
International journal on urban environments

hiked price ${ }^{\mathrm{e}}$ is not adequate in the face of rising land value and they have to resettle in fewer cents of land. Except in the case of smart city displaced, majority of the displaced in other projects rebuilt the houses in their own land and not in the rehabilitation land. Given the uncertainty of rehabilitation package and its delivery and with inflating prices day by day, people were astute enough to start rebuilding houses in any remaining land or in any additional land which they owned or by purchasing a few cents of land either in the same region or nearby areas. In some areas, where the price of land was already high and shot up post the declaration of project, people were forced to purchase land in more interior places. They point out their accumulated indebtedness and the associated vulnerability. Augustine, a displaced person puts it rather drastically, "we stand the risk of japthi (seizing of title deeds) and if it happens you would see mass suicide", indicating the absolute vulnerability of the coupling of indebtedness with the day to day existence of labourers like him (which again is crucially tied to their health). In some cases, women who had never done paid work have started going for work in order to meet their interest obligations. An empirical examination of proportion of indebted people and level of indebtedness is presented in the following two tables.Table 6 presents a comparison between IDPs and non-IDPs with regard to indebtedness.

Table 6: Comparison of IDPs and NON IDPs having debts

\begin{tabular}{|l|r|r|}
\hline Having Debts & \multicolumn{1}{|c|}{ IDP } & \multicolumn{1}{c|}{ NON IDP } \\
\hline Not answered & $2(0.5)$ & $11(2.5)$ \\
\hline Yes & $245(65)$ & $203(45.3)$ \\
\hline No & $130(34.5)$ & $234(52.2)$ \\
\hline Total & $377(100)$ & $448(100)$ \\
\hline
\end{tabular}

Around 65 percent of the displaced are indebted at present when compared to 45.3 percent of the non-IDPs. Studies on poor and working class have pointed out how it is common among them to have debt, a possible reason why debt is high even among the non-IDP (George, 2001, 2010). However there is indeed a considerable difference in the proportion of people having debt between IDP and non-IDPs. Also the amount of debt is higher among the IDPs than the non-IDPs (See Table 7)

Table 7: Average debt amount with IDPs and Non IDPs

\begin{tabular}{|l|c|c|}
\hline & N & Mean \\
\hline IDP & 245 & 244135 \\
\hline NON IDP & 202 & 228802 \\
\hline Total & 447 & 237206 \\
\hline
\end{tabular}

${ }^{\mathrm{e}}$ District Level Purchasing Committee- an institution formed in the context of land acquisition for deciding on the compensation price for the displaced. People got twice the amount of the basic value of the land. 
International journal on urban environments

\section{Comment on material impoverishment and inequality}

In sum, majority of the displaced did not experience an impoverishment in the considered dimensions, be it housing, possession of consumer durables, income and changes in income post displacement. In fact, in some places, land acquisition seem to have given people an opportunity of acquiring a higher value for the otherwise low priced land because of the un-viability of agriculture. Therefore what happened was conversion of one asset to another one- of excess land to better houses. As mentioned before, it could also be because they have resettled close and thereby their work and social relations and distance to amenities were not severely affected.

However, although not the majority, there are families who have not been able to rebuild their houses even after years of eviction. Loosing entire land, having only a few cents of land to begin with, which could beget only a low compensation amount (even if they get more cents of land in rehabilitation, it was given after some years and some of the land have not been properly developed yet), having many claimants to the compensation amount, having some legal issues to their land and having other pressing concerns like getting their children married off or getting their children to go abroad are some reasons seen behind the inability to settle even at present.

In many of the above mentioned dimensions of material well-being, one does not find striking difference between the IDPs and non-IDPs or the general population, from which we may infer that the displacement has not been particularly inequality widening within a locality. However in terms of income earning potential, we find the non-IDPs clearly having an advantage with higher possession of highly priced land. In our qualitative fieldwork, we heard allegations of outsiders purchasing a lot of land in these areas having come to know about the upcoming projects before hand from their political and bureaucratic connections. People alleged that the road alignments were redrawn to suit the real estate interests of the rich and powerful. Not surprisingly, several high rises have sprang up, particularly in those areas of Kochi adjacent to the infrastructure projects of ICTT road and Goshree bridges. At times, these high rises are built flouting environmental norms. One of the Goshree bridges displaced, who has resettled on her own in the lake front says how panchayat has not issued a house number to her as the house is located in a coastal regulation zone. She points at the several high rises across the lake and asks why such rules are not applicable to them.

\section{Violence and safety}

One of the major queries of this research was to examine if displacement through the possibility of accentuation of poverty and severing of social networks make the displaced more vulnerable to violence understood in its most basic form of physical force and injury to person and property or insecurities of violence. Table shows the findings with regard to the selected dimensions of safety and insecurity considered in this study. 
International journal on urban environments

Table 8: Violence and insecurity

\begin{tabular}{|c|c|c|}
\hline & IDP & Non-IDP \\
\hline \multicolumn{3}{|c|}{ Perceptions and experiences of safety in the neighbourhood } \\
\hline $\begin{array}{l}\text { Perceive neighbourhood to be safe in } \\
\text { day (saying definitely) }\end{array}$ & 91.5 & 99.7 \\
\hline $\begin{array}{l}\text { Perceive neighbourhood to be safe in } \\
\text { night (saying definitely) }\end{array}$ & 88.1 & 97.8 \\
\hline $\begin{array}{l}\text { Eve teasing of women in } \\
\text { neighbourhood (denying its } \\
\text { existence) }\end{array}$ & 93.9 & 99.1 \\
\hline $\begin{array}{l}\text { Publicly visible social miscreants in } \\
\text { neighbourhood (denying its } \\
\text { existence) }\end{array}$ & 86.9 & 97.8 \\
\hline \multicolumn{3}{|c|}{ Actual experiences of violence in the last one year } \\
\hline Verbal abuse (not experiencing) & $367(97.3)$ & $445(99.3)$ \\
\hline $\begin{array}{l}\text { Someone got into the house to steal } \\
\text { (no such experience) }\end{array}$ & $368(97.6)$ & $445(99.3)$ \\
\hline $\begin{array}{l}\text { Someone taking something by force } \\
\text { (no such experience) }\end{array}$ & $373(99.2)$ & $446(99.8)$ \\
\hline $\begin{array}{l}\text { Steal something stored outside (no } \\
\text { such experience) }\end{array}$ & $368(97.6)$ & $446(99.8)$ \\
\hline $\begin{array}{l}\text { Deliberate damage to property (no } \\
\text { such experience) }\end{array}$ & $375(99.5)$ & $447(99.8)$ \\
\hline $\begin{array}{l}\text { Assaulted or threatened (no such } \\
\text { experience) }\end{array}$ & $373(98.9)$ & $445(99.6)$ \\
\hline $\begin{array}{l}\text { Kidnap or disappearance (no such } \\
\text { experience) }\end{array}$ & $377(100)$ & $448(100)$ \\
\hline
\end{tabular}

As shown by the table, the displaced have not experienced the selected crimes and insecurities of this study. This is possibly because people have resettled nearby and a major rupture of social relations and people to help has not happened. There is nothing in our data to suggest that the displaced are more prone or susceptible to violence. The violence relevant in our study is that of state violence which was heard of during our quantitative survey and which was probed more intensely in the later qualitative research. We present the details of state violence in the next section.

\section{Findings from qualitative field work}

\section{State violence of various forms}

While the quantitative survey enquired dimensions of poverty, inequality, physical safety and insecurity, it soon became clear (as is shown from our data) that these were not the pressing concerns of the people. We found that people were very 
International journal on urban environments

aggrieved and angry about their entire displacement experience. State violence in terms of brute force (rare but deployed in some instances), threats and intimidation, offering poor deal and also in terms of inefficiency and apathy or indifference in executing a speedy delivery of promises have led to poignant grievances for the displaced. In the six projects covered in this study, forceful eviction was deployed only in one place called Moolampilly on February 6, 2008, for the ICTT road project. Moolampilly since then gets etched in the displacement discourses of Kerala and India. Mahashwetha Devi, a famous writer in India for instance refers to Moolampilly as Kerala's Singur and Nandigram (two places in West Bengal in India, which came to be well known for people's resistance against land acquisition). Of the 22 families to be evicted from Moolampilly for the laying of National highway road to ICTT terminal, 12 families give consent by accepting the compensation. But 10 families stand firm on their protest. On that day, without any prior information district authorities demolished the houses of the proposed evictees who had not given consent. Things including cooking pots and children's books are taken away by the authorities. A lot of confusion and helpless crying follows. Children return home to find their houses demolished. Even the sick elderly was not spared. The episode becomes the catalyst event invoking widespread criticism against authorities and turning the tide in favour of the victims. However, those who experienced it can recall the incident and the ensuing few days of camping in a school building only with dread and pain.

While the instance of brute force is limited to one (although media keeps reporting other instances connected to other displacement), several instances of threat, along with cajoling stances of the government officials were told. A major threat was that if the people protested, they would not even get the District Level Purchasing Committee determined price, but would have to go to the court. Reportedly, people were also given false promises of land, when such offers were not there in the first place and later when land was being offered, the authorities tried to cajole people to accept land elsewhere (rather than in the same village) saying that the land offered would get good asset value. The manner in which threats are issued, where they are told that they will be responsible for their plight is also revealing; for instance, the land acquisition officer says "time for DLPC negotiations is also over, but nevertheless will arrange it for you; I do not want forceful eviction and you will be responsible for it".

The state violence is also about offering a poor and insensitive deal to the displaced. For instance, an interviewee narrated how the land acquisition officer suggests that they take the compensation amount offered and get land for themselves in far off places where land prices are low. This statement of the LA officer emanated from compensation norms that existed till then and practical suggestions to victims to cope with it, but it also indicates a general ease of offering a poor deal for the poor or the commoner. In fact, it is this poor deal given as compensation for evicting from their homes, which form their core grievances culminating in even suicides in a couple of cases. Later, when they won better compensation packages, state violence manifested as failure of its execution, in turn continuing to agonise the displaced. 
International journal on urban environments

\section{People's agency: Fighting against impoverishment, inequality and violence}

"I told categorically that only after land is given, we will move out; I asked them how are we supposed to get land for this price offered as compensation? I have asked the district collector myself that with this compensation amount, can we even purchase some loads of sand?....He is the collector, right; but whatever or whoever he is, he cannot go against justice and fairness; collector is also a protector of people and not someone who chases them away from their homes to become beggars of the street".

Neither highly educated, nor employed Mary Agnus' categorical and unwavering awareness of her rights of a proper rehabilitation by and large represented the struggle of the ICTT displaced; mostly people with working class jobs (as we saw in the earlier discussion), but keenly aware of the problems of a mere cash compensation based rehabilitation package. One finds the launch and execution of a prolonged struggle (agitations, litigations and so forth) for a fair compensation in case of three projects (Goshree, ICTT, Smart City). People's struggle in case of Brahmapuram waste plant was to prevent its commissioning in their village in the first phase and later for their own eviction when the plant got commissioned. The displaced formed co-ordination committees along with activists and carried out several methods of protest namely carrying out satyagraha for days together, staging protest marches, filing litigations and conducting several rounds of meetings, negotiations and discussions with the officials and political leaders. As mentioned before the Moolampilly forceful eviction becomes the catalyst event invoking widespread criticism against authorities and inviting attention to the struggle. The victims although shocked at first however garnered their presence of mind and call the visual and print media. The forceful eviction gets aired, human rights commission intervenes and the land acquisition officer is made to apologise. Government then promised improved rehabilitation package for the ICTT, which came to be known as the Moolampilly package.

These struggles are in a sense their fight against all the three dimensions examined in the study- of poverty, inequality and state violence of various forms. From the very beginning people are conscious of the pitfalls of mere cash based compensation. The DLPC price is a solatium added to the registered market prices of the land then. Given that it is an open secret that most land transactions in India are grossly undervalued to evade registration fees and given that compensation amount given after the handing over of documents and house keys cannot compete with the market rate of land which starts appreciating from the time of notification or freezing of land, even the DLPC hiked price is not adequate in resettling in the same region. The displaced were astute enough to demand land for land for cushioning the impoverishment impacts. In some areas, where the price of land was already high and shot up post the declaration of project, people were forced to purchase land in more interior places. The demand of land for land within the same village or nearby areas could also be seen as their attempts to partake in the benefits of the development projects for which they had to bear hardships While being quite helpless about the amplified inequality contained in these changes, they however stood firm on this demand for some participation in the benefits of the development projects. As Selestian 
International journal on urban environments

puts it "Don't the displaced also need development?".Finally, their relentless fight against state violence of various forms yielded results to varying extent in the different projects. As a result of these struggles, Smart City and ICTT evictees get a much better compensation package. The struggle of Goshree evictees still continue as even today they have not got a clear nod from district authorities on their demand. In Brahmapuram, their demands in the first part does not get accepted but they are given a compensation amount after which there have been no agitations, although litigations are there for a higher compensation price. In case of ICTT, the rehabilitation package containing land for land is a historic, given that the national policy on highways and railways provides for only cash based compensation. However, till date the promises have not been completely executed.

\section{Heterogenous experiences of the displaced}

How far people are satisfied/ distressed with the process of resettlement depends on a variety of factors. To begin with, there is the question of use or harm value which was brought in by the development projects. For instance, the Goshree bridges which connected the cut off islands to the main land, the ICTT road which made city, just a ten minutes away (as the displaced presented it) are clear examples of use value of a project. The ones with use value can also generate demerits. The ICTT road construction led to many a paddy and prawns field become useless as it cuts through them. There is clear harm value to certain projects like Brahmapuram waste plant.

Second, the use and asset value described above would make sense only if they have been able to re-settle nearby itself. This again depend on the success of their agitations, which in turn depend on several other factors like their numerical strength, the unity of the movement, the type of project (whether it is state or central government), the support they receive from political leaders or civil society or media or the non displaced in the region, ready availability of resources, the time period of eviction and so forth. For instance, Smart city rehabilitation is one project which may be considered as a rare successful finish to a struggle where the displaced express satisfaction with their rehabilitation. They got land for land with a bonus of all nuclear units within a joint family getting separate land. Importantly there was a speedy delivery of the promises. In case of ICTT displaced, although their struggle saw them being offered better rehabilitation package, the promises are still not executed. Both struggles received much media attention and support from civil society. The difference in success probably lie in smart city displacement being a state government project, the displaced being numerically less, and geographically limited and good land being readily available, where as in case of ICTT it is a central government project, the displaced being numerically large and from different locations and good land not being readily available (which then bring in increased scope for inefficiency to creep in as land has to be developed). For the same reason, the ICTT displaced, although now resettled, now looks back at the displacement episode with angst and grievance. The Goshree evictees despite the struggle being the longest, have not got their demands accepted. What one finds is that with time, as a result of the victim's continuous struggles for their rightful compensation, the projects which came later like ICTT and Smart City, as discussed 
International journal on urban environments

above are offered better compensation packages. As one compensation package became a precedent for the next, Goshree displaced suffered from the fact of being one of the first projects. This compounded with the fact of them being numerically less meant that the attention and championing of civil society was also missing in their struggle.

\section{Conclusion}

Literature on development induced displacement talks of the impoverishing, inequality exacerbating and violence laden experiences of the displaced across India. In this paper we sought to understand whether the experiences of the displaced, in the state of Kerala, well known for its apparent pro-poor approach and public consciousness of its people, would be similar or different from experiences elsewhere in India.

The study finds that as noted from elsewhere it is the lower strata which formed the majority of the displaced. However, there has not been an impoverishment of people as indicated by the material dimensions of their lives. But the displaced have higher proportion and levels of debt than the non- displaced. A comparison between IDPs and non-IDPs show that in terms of the current level of material living conditions, the displaced are slightly better off but in terms of future income potential (based on land ownership of high valued land) the non-displaced are at far more advantage. But more than the inequality amongst the insiders of the region (even the non-IDPs belonged to weaker sections), it is probably the outsiders purchasing land before the commencement of projects and thereby benefitting unduly which forms the central issue of inequality (although these are anecdotal comments heard during survey and not empirically probed in this study). Physical safety and security were not serious issues among the displaced. However, state violence in the forms of indifference, negligence, inefficiencies led to great deal of anger and unnecessary suffering for the displaced.

The larger point that one infers from these findings is how the state of Kerala continues to be what development discourses on the state has already identified as its positive and negatives. In the agency of the people across projects one finds a continuum of its historical pattern of a public, conscious of its rights and acting relentlessly to achieve the same which reflects positively on the state.

On the negative side, we find that the state, despite the wide acclaim for being pro- poor and pro-people handled the displacement experience in a similar manner to what happened elsewhere in India. The difference however can be seen where state used brutal force. As may be recalled, we saw instances in Ahmedabad and Delhi where people were brutally thrown out from homes and the state could get away with such actions. In Kerala, the one act of brutality led to widespread and strong criticisms from all - from people, intelligentsia, political parties and so forth. This also led to the declaration of better compensation packages. But in all the subtler and non- physical forms of violence, the actions of the state are comparable to what happened elsewhere in India- be it in the threatening and cajoling stances, be it in the non-delivery or slow delivery of promises and so forth.

Finally the heterogeneity of experiences of the displaced in different projects also highlight a weak point of the state (and centre), of not having a standard norm for 
International journal on urban environments

land acquisition and moving from one compensation package to another, depending on the pressure exerted on it at a point of time. However it is not a problem of the state alone. It is only in 2013 when an act combining land acquisition and rehabilitation, namely the 'Right to fair compensation and transparency in land acquisition, rehabilitation and resettlement act of 2013' was passed. The new government which came in 2014 has made many significant amendments to the act through an ordinance and the fate of the 2013 act remains to be seen.

Having said that, however, these evolving packages did show, what would best work to make a win -win situation. There are indeed lessons to be learnt from successful and satisfactory rehabilitation experiences, as in the case of smart city displaced. In the urban or urbanising context, where fundamental conflicts over land acquisition may be coming down, people would be willing to bear the hardships of displacement and resettlement if the rehabilitation package allows them to settle even a little better. We have not considered ecological issues in this paper, which complicates the displacement issues further and makes the challenges for a win-win solution harder.

\section{Acknowledgements}

This work was financially supported by IDRC, Canada.

\section{References}

Asthana Vandana (2012) 'Forced Displacement: A Gendered Analysis of the Tehri Dam Project'. Economic \& Political Weekly, Vol. XLVII, No. s 47 \& 48.

Baviskar, Amita (2011) 'What the Eye Does Not See: The Yamuna in the Imagination of Delhi'. Economic \& Political Weekly, Vol - XLVI No. 50.

Bhan Gautam, and Swathi Shivanand (2013) '(Un)Settling the City: Analysing Displacement in Delhi from 1990 to 2007', Economic and Political Weekly, Vol - XLVIII No. 13.

Coelho Karen, T Venkat and R Chandrika (2012) 'The Spatial Reproduction of Urban Poverty: Labour and Livelihoods in a Slum Resettlement Colony', Economic and Political Weekly, Vol - XLVII No. 47-48.

Cook, Ian, Ramachandra Bhatta, Vidya Dinker (2013) 'The Multiple Displacements of Mangalore Special Economic Zone', Economic and Political Weekly, Vol - XLVIII No. 33

Economic and Political Weekly (2014) 'Editorial- Of Land and Livelihoods', Economic and Political Weekly, Vol XLIX No 1.

George Ann (2001) Multiple Dimensions of Well being: A micro level study of the poor, Unpublished M. Phil Thesis, Centre for Development Studies, Trivandrum.

George Ann (2010) Understanding lives of the poor using Capability Approach: A micro level study of poor waste picking women in the urban areas of Ernakulam district, Unpublished Ph.D Thesis, Madras University, Chennai.

Institute of Applied Manpower Research (2011) India: Human Development Report, 2011: Towards Social Inclusion, Planning Commission, Government of India

Mathur Navdeep (2012) 'On the Sabarmati Riverfront: Urban Planning as Totalitarian Governance in Ahmedabad', Economic and Political Weekly, Vol - XLVII No. 02.

Sampat Preeti(2014) 'On the Land Question in 21 st Century India', Economic and Political Weekly, Vol XLIX No 30 .

Sarma, E A S (2011) 'Sops for the Poor and a Bonus for Industry', Economic and Political Weekly, VOL XLVI No. 41

Roy Arundathi (1999) The Greater Common Good, http://www.narmada.org/gcg/gcg.html as accessed on 04-07-2015

World Health Organization (2002) World Report on Violence and Health, WHO, Geneva. 